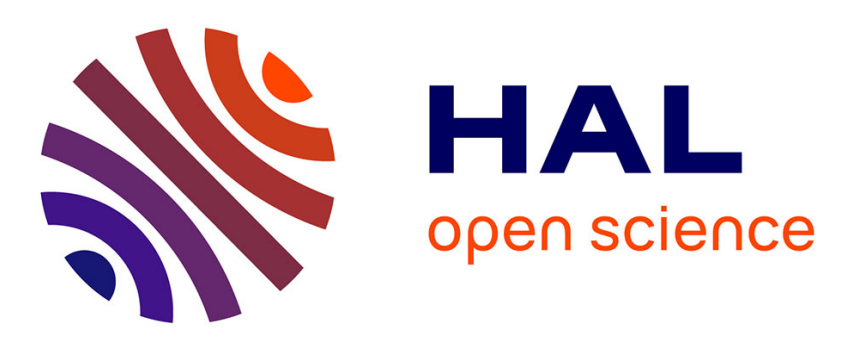

\title{
Consumption pattern, biochemical composition and nutritional value of fermented pearl millet gruels in Burkina Faso
}

Claire Mouquet Rivier, Christèle Icard-Vernière, Jean-Pierre Guyot, E. Hassane Tou, Isabelle Rochette, Serge Trêche

\section{To cite this version:}

Claire Mouquet Rivier, Christèle Icard-Vernière, Jean-Pierre Guyot, E. Hassane Tou, Isabelle Rochette, et al.. Consumption pattern, biochemical composition and nutritional value of fermented pearl millet gruels in Burkina Faso. International Journal of Food Sciences and Nutrition, 2008, 59 (7-8), pp.716-729. ird-01225661

\section{HAL Id: ird-01225661 \\ https://hal.ird.fr/ird-01225661}

Submitted on 6 Nov 2015

HAL is a multi-disciplinary open access archive for the deposit and dissemination of scientific research documents, whether they are published or not. The documents may come from teaching and research institutions in France or abroad, or from public or private research centers.
L'archive ouverte pluridisciplinaire HAL, est destinée au dépôt et à la diffusion de documents scientifiques de niveau recherche, publiés ou non, émanant des établissements d'enseignement et de recherche français ou étrangers, des laboratoires publics ou privés. 


\section{Consumption pattern, biochemical composition and nutritional value of fermented pearl millet gruels in Burkina Faso}

Mouquet-Rivier Claire ${ }^{1 *}$, Icard-Vernière Christèle ${ }^{1}$, Guyot Jean-Pierre ${ }^{1}$, Tou El Hassane ${ }^{2}$, Rochette Isabelle ${ }^{1}$, Trèche Serge ${ }^{1}$.

${ }^{1}$ UR106 « Nutrition, Alimentation, Sociétés ", Institut de Recherche pour le Développement, BP 64501, F-34394 Montpellier cedex 5, France

2Université de Ouagadougou /UFR-SVT/ CRSBAN, Burkina Faso

*corresponding author: Email: claire.mouquet@ird.fr ; tel: 0033467416295

Abbreviated running title: Consumption and composition of fermented pearl millet gruels

Please cite as follows:

Mouquet-Rivier, C., Icard-Vernière, C., Guyot, J.-P., Tou, E. H., Rochette, I., \& Trèche, S. (2008). Consumption pattern, biochemical composition and nutritional value of fermented pearl millet gruels in Burkina Faso. International Journal of Food Sciences and Nutrition, 59(7), 716 - 729. 


\section{Abstract}

Ben-kida and ben-saalga are popular pearl-millet-based fermented gruels in Burkina Faso. A survey of 318 households in Ouagadougou (Burkina Faso) showed that they are often used as complementary food for young children. Pearl millet and gruels, sampled in 48 production units were analysed for proximate composition, factors reducing nutrient bioavailability (phytate, insoluble fibres and iron-binding phenolic compounds), alpha-galactosides, sugars, total lactic acid and D-lactic acid, zinc and iron contents. The effects of processing of pearl millet into fermented gruel are discussed. Both positive effects, e.g. a decrease in factors reducing nutrient bioavailability or alpha-galactosides, and undesirable effects, e.g. considerable lipid, protein, iron and zinc losses were observed. Lactic acid was produced during processing and $\mathrm{D}(-)$ lactate was detected in all samples.

The gruels had very low energy density, even after addition of sugar, and low lipid, protein and mineral contents, well below recommendations for complementary foods.

Keywords: pearl millet; fermented gruel; energy density; nutritional value; phytate; alphagalactosides

\section{Introduction}

Fermented cereal gruels prepared mainly from maize, sorghum or millet are widely eaten in West Africa (Blandino et al., 2003). In urban areas, they are produced at a small scale in informal micro-enterprises. Gruels are usually prepared in the yard of the homestead by one woman, who is sometimes helped by another member of the family. In Ouagadougou, the gruels are prepared from pearl millet (Pennisetum glaucum) every day, sold in ready-to-eat form with a ladle by the producer just in front of her home or at the local market. In mooré, the language of the Mossi, one of the main ethnic groups of Burkina Faso, the gruels are called ben-kida or ben-saalga, depending on whether pearl millet flour granules are added during cooking or not. Ben-kida and ben-saalga are mainly eaten as breakfast. The processing of pearl millet into ben-saalga or ben-kida has already been described in detail by Tou et al. (2006). It comprises five main steps: soaking of the grains, milling, sieving, decantation and cooking. Lactic acid fermentation occurs during the decantation step, leading to the final low $\mathrm{pH}$ and giving the gruels a sour taste. The processing sequence is very similar to that used to produce other African fermented gruels (Blandino et al., 2003; Lei and Jakobsen, 2004).

The nutritional value of these gruels depends on the intrinsic nutritional quality of cereals (McKevith, 2004), on the effect of the different processing steps and on the value putatively added by fermentation (Chavan and Kadam, 1989). However, the pearl millet used to prepare the gruels is purchased by small producers at traditional retail markets in Ouagadougou. Pearl millet grains are sold as a mixture of genotypes that are not very well identified and whose composition varies with the genotype and the environmental conditions during cultivation (Buerkert et al., 2001; Ouattara et al., 2006). Added to variability caused by differences in processing conditions between traditional production units (Tou et al., 2006), this can result in variability in gruel composition. Since these gruels are frequently given to young children as complementary food (Blandino et al., 2003), a great deal of care has to be paid to their 
nutritional quality, above all to micro- and macronutrient density and in particular to energy density (Trèche and Mbome, 1999; Dewey and Brown, 2003).

The objectives of our study were first to identify the consumption pattern of the two types of pearl millet gruels in Ouagadougou, and second to characterize the nutritional quality of gruels produced in the field and its variability, in order to assess their suitability as complementary foods for infants and young children.

\section{Material and methods}

\section{Collection of data on the consumption pattern of fermented millet gruels}

To identify the consumption pattern of fermented millet gruels, a survey was made of 320 households in Ouagadougou, among which 160 consumed such gruels and 160 did not. The households were selected at random by cluster sampling in 29 of the 30 administrative areas of the town of Ouagadougou (area $n^{\circ} 4$ was discarded because it contains mainly administrative buildings and ministries). Eighty points distributed in the 29 areas as a proportion of their population were determined graphically on the map of each area of the town, and from each point, two households who consumed the fermented gruels and two households which did not were interviewed. A household was considered as a "consumer household" (CH) when someone in the household had consumed ben-kida or ben-saalga at least once in the month preceding the day of the survey. Otherwise, the household was considered as a "non-consumer household" (NCH). To obtain the $2 \mathrm{CH}$ and $2 \mathrm{NCH}$ at each point selected for the survey, it was sometimes necessary to visit more than 4 households. In order to estimate the extent of consumption of fermented millet gruel by people living in Ouagadougou, all the households visited were noted and classified as $\mathrm{CH}$ or $\mathrm{NCH}$. The person interviewed in each household was the one responsible for the preparation of the meals for the whole family. The questionnaire included two parts. The first part aimed at collecting data on the frequency and way of consumption of the fermented gruels and their usual suppliers. The second part concerned the perception of the quality of the gruels. Data concerning the socio-cultural and economic profile of the household were also recorded.

\section{Collection of samples for biochemical analyses}

The survey enabled the identification of 130 ben-kida or ben-saalga production units (PU) in Ouagadougou. Samples of raw millet and final gruels - ben-kida or ben-saalga, depending on the type of gruel produced in the PU - were taken in 48 of them, which were selected at random. To detect possible seasonal variability of the composition of gruels, samples were collected over a period of one year at the rate of four pairs of samples (raw millet and final gruel) per month from four different PUs. Final gruels were sampled as sold by the producers, without added sugar. All the samples were taken back to the laboratory where part was used for analyses of dry matter content and measurements of consistency and $\mathrm{pH}$. The rest was freeze-dried, ground (particle size $<500 \mu \mathrm{m}$ ) and stored at $-18^{\circ} \mathrm{C}$ until further analyses. An average sample was made by mixing identical aliquots of the 48 samples of raw millet seeds, 
ground and analysed. The variability of the composition of raw millet was assumed to be rather limited and was assessed by analysing only 14 samples which were selected at random.

\section{Measurement of $\mathrm{pH}$ and consistency}

The $\mathrm{pH}$ of the gruels was determined at room temperature using a WTW 340i pH-meter with automatic compensation of temperature.

The consistency of the gruels was measured after cooling at $45^{\circ} \mathrm{C}$ using a Bostwick consistometer according to the procedure described by Mouquet et al. (2006). The Bostwick consistency parameter is expressed in $\mathrm{mm} / 30 \mathrm{~s}$. This parameter ranges from 0 (almost solid) to $>240 \mathrm{~mm} / 30$ s (very fluid, corresponding to a gruel that can be drunk).

\section{Biochemical analyses}

\section{Proximate composition}

Dry matter (DM) contents were determined by oven drying at $105^{\circ} \mathrm{C}$ to constant weight. Protein contents $(N \times 6.25)$ were determined by the method of Kjeldahl (standard NF. V03050, AFNOR, 1970). Lipids were extracted with ether oil using the HT6 Soxtec system (Tecator, Höganäs, Sweden) according to the AOAC official method 2003.06. Insoluble fibre (Acid Detergent Fibre, ADF) contents were determined by the method of Van Soest (1963) using a Dosi-fiber (Selecta, Barcelona, Spain). ADF corresponds approximately to cellulose and lignin, which are the compounds of fibres most likely to chelate minerals. Determination of residual ashes and proteins (as Kjeldahl $\mathrm{N} \times 6.25$ ) was carried out in the residues for corresponding corrections. Ash contents were determined by calcination in a furnace at $530^{\circ} \mathrm{C}$. Available carbohydrates were calculated by difference (100 - proteins - lipids - ADF - ashes). Energy density of the gruels was then calculated by using Atwater coefficients: $4 \mathrm{kcal} / \mathrm{g} \mathrm{DM}(16.7 \mathrm{~kJ} / \mathrm{g}$ DM) for proteins and available carbohydrates and $9 \mathrm{kcal} / \mathrm{g}$ DM (37.6 kJ/g DM) for lipids.

\section{Soluble carbohydrates}

After extraction in ethanol solution $(80 \% \mathrm{v} / \mathrm{v})$, and drying using a Speedvac centrifugal evaporator (JOUAN RC 10-10, Saint Herblain, France), soluble carbohydrates were analysed by HPAE-PAD using a Dionex DX 500 apparatus (Sunnyvale, CA, USA) with a Carbo PA1 column according to the method described by Calderon et al. (2001). The soluble carbohydrates that were analysed in gruel samples were glucose, fructose, sucrose, maltose, and alphagalactosides, i.e. melibiose, stachyose and raffinose. The eluant used was $90 \mathrm{mM}$ sodium hydroxide solution.

\section{Iron and Zinc contents}

After mineralization at $530^{\circ} \mathrm{C}$ (Laporte et al., 1980), total iron and zinc contents were determined by atomic absorption spectrophotometry (SpectrAA 200, Varian, Victoria, Australia). 


\section{Compounds reducing nutrient bioavailability}

\section{Phytate}

Inositol 6-phosphate contents were determined according to the method described by Talamond et al. (1998). After extraction in acid solution (HCl $0.5 \mathrm{M}$ ), inositol-6-phosphate (IP6) content was determined by ionic chromatography using a Dionex DX 4500i apparatus equipped with an Ion Pac AS11 column. Detection was by conductivity. The values are expressed in g IP6/100 g DM.

\section{Iron-binding phenolic compounds}

Iron-binding phenolic compounds were analysed according to the colorimetric method of Brune et al. (1989) using a ferric ammonium sulphate reagent which enabled measurement of galloyl and catechol group contents at 578 and $680 \mathrm{~nm}$, respectively. Results are expressed as the sum of the tannic acid and catechin equivalent in $\mathrm{g} / 100 \mathrm{~g}$ DM.

\section{Lactic acid and D-lactic acid contents.}

Total lactic acid content of gruels was determined by HPLC using an Aminex HPX687H column (Biorad, Ivry sur Seine, France). D-lactic acid content was determined by a colorimetric method using the kit EnzyPlus ${ }^{\mathrm{TM}}$ D-lactic acid (Raisio Diagnostics, Lyon, France).

\section{Data management and statistical analysis}

Survey data were captured and analysed using Epi Info 6.04d software (CDC, Atlanta).

The results of biochemical analyses were checked for normality using the KolmogorovSmirnov test. For the variables that approximated a normal distribution, the mean value, the minimum and maximum values, and the standard deviation are given. For variables that did not pass the normality test, the median value is also given.

\section{Results and discussion}

\section{Consumption pattern of fermented millet gruels}

To reach the initially desired sample size of $160 \mathrm{CH}$ and $160 \mathrm{NCH}$ (two of each at each of the 80 survey points of the town), a total of 521 households were visited, comprising $342 \mathrm{CH}$ and $179 \mathrm{NCH}$. This allowed us to estimate that $65.6 \%$ of the households in Ouagadougou are "consumers" of this type of gruel, i.e. had consumed ben-kida or ben-saalga during the month before the survey.

\section{Extent and conditions of consumption}

Almost half $\mathrm{CH}$ consumed fermented gruels daily, mainly early in the morning, for breakfast (Table 1). As it was stated by Blandino et al. (2003) for fermented cereal gruels in other WestAfrican countries, people of all ages ate the gruels and young children under the age of two appear to be frequent consumers: $80 \%$ of them in the $\mathrm{CH}$ had consumed the last gruel that had been purchased by the household and almost $70 \%$ consumed it every day. Several mothers reported that the liquid ben-saalga is given to the younger, and that children begin 
to receive ben-kida when the first teeth appear. Sugar was added before consumption in $98 \%$ of cases. The weighing of the amounts of sugar and gruel purchased at the same time at one point of sale by 10 different customers enabled us to estimate that the mean concentration of added sugar was $4.4 \mathrm{~g} / 100 \mathrm{~g}$ of sweetened gruel. Almost $75 \%$ of the consumers ate only the gruel; the remainder ate it with cake or bread to fill the stomach better. The gruels were either eaten immediately where they were purchased, or taken home for the whole family. Ben-kida was by far the most popular and most often consumed type of gruel $(83 \%$ of $\mathrm{CH}$, against $17 \%$ for ben-saalga) mainly because it was perceived to be more nourishing and substantial.

\section{Socio-cultural and economic context of the consumption of ben-kida and ben-saalga}

The weekly frequency of consumption of fermented millet gruels by the households in Ouagadougou is independent of their ethnic group, their religion and their urban or rural origin. But the mean weekly frequency was significantly higher $(p<0.05)$ in households where the head was older or less educated, had more than four children, or a lower socio-economic status.

\section{Demand and preferences of consumers}

The main reasons most frequently given by people for consuming or not consuming ben-kida or ben-saalga are listed in Figure 1. These results highlight the very good acceptability of the fermented gruel and also the importance of the convenience of such ready-to-eat products (figure 1b). Among NCH, 31\% declared they did not know much about this type of gruel as it was not part of their food habits (figure 1a). The second reason for not consuming fermented millet gruel was that it is not nutritious enough: according to $26 \%$ of them, it fills the stomach but it does not last a long time, and "it does not kill hunger". The third main reason was the gruels' reputation for poor hygienic quality. Only $7 \%$ of $\mathrm{NCH}$ said it was too expensive.

More than $70 \%$ of $\mathrm{CH}$ and $\mathrm{NCH}$ interviewed made suggestions for improvement: respectively 46 and $39 \%$ would like producers to pay more attention to hygiene during preparation and at points of sale; 31 and $45 \%$ of $\mathrm{CH}$ and $\mathrm{NCH}$ would like a more substantial or nutritious gruel, even enriched with vitamins. Many people also said that more aromatic ingredients, such as ginger, mint, and tamarind, should be used to improve the taste of the gruels.

\section{Biochemical composition and nutritional value of the fermented millet gruels}

The main physicochemical characteristics of the fermented millet gruels are presented in Table 2. The Bostwick flow values are high, corresponding to very fluid gruels, which can either be eaten with a spoon or drunk. Only one gruel had a Bostwick flow value higher than $240 \mathrm{~mm} / 30$ s and was considered as an outlier with an undesirable consistency. To obtain such a fluid consistency, producers must dilute the gruels considerably, which results in low dry matter contents, most between 5 and $8 \mathrm{~g} / 100 \mathrm{~g}$ of gruel (figure 2) and consequently low energy density, below $133.8 \mathrm{~kJ}(32 \mathrm{kcal}) / 100 \mathrm{~g}$. Three outliers, all three of the ben-kida type, had higher concentrations that may be due to the addition of larger quantities of flour granules. Nevertheless, there was no significant difference between the concentrations of 
ben-saalga and ben-kida. And the maximum value did not exceed $10.24 \mathrm{~g}$ of DM/100g of gruel, corresponding to an energy density of about $171 \mathrm{~kJ}(41 \mathrm{kcal}) / 100 \mathrm{~g}$, which is far below the minimum energy density of $351 \mathrm{~kJ} / 100 \mathrm{~g}(84 \mathrm{kcal} / 100 \mathrm{~g})$ recommended for complementary food (Dewey and Brown, 2003).

Due to lactic acid fermentation that occurs during processing (Tou et al., 2006), fermented gruels have a low $\mathrm{pH}$ that gives them a sour taste. The $\mathrm{pH}$ of the gruels of the ben-kida type is slightly but significantly $(\mathrm{pH}<0.05)$ higher than that of gruels of the ben-saalga type, which may be explained by the addition of granules prepared with unfermented flour. Nevertheless, all $\mathrm{pH}$ values were below 4.5, most were near 4.0, like all other African cereal-based gruels that undergo lactic acid fermentation, such as ogi and mahewu (Simango, 1995), or togwa (Chavan and Kadam, 1989). In the poor hygienic conditions that prevail in production units in developing countries, this low $\mathrm{pH}$, combined with the production of lactic acid, $\mathrm{H}_{2} \mathrm{O}_{2}$, diacetyl and bacteriocins, has the advantage of preventing or limiting the growth of food-borne pathogens or undesirable microorganisms, even after cooking (Nout et al., 1989; Kingamkono et al., 1994; Blandino et al., 2003). The variability of the $\mathrm{pH}$ of fermented millet gruels was low, 75\% had a pH between 3.89 and 4.09 (figure 3).

Data on proximate and mineral composition of raw millet and fermented millet gruel are given in Table 3. Millet grains are richer in proteins and lipids than most other cereals available in west-africa, such as rice, maize, sorghum (FAO, 1995). The iron content of the raw millet was highly variable with a maximum value around $74 \mathrm{mg}$ of iron/100g of DM. It is likely that such a high value corresponds not only to intrinsic iron, but also to additional iron from dust or ferrous soil as it has been previously shown for tef (Abebe et al., 2007). Mean values of iron and zinc content ( 22.7 and $2.47 \mathrm{mg} / 100 \mathrm{~g} \mathrm{DM}$, respectively) are higher (for iron) and similar (for zinc) than recently reported values obtained from samples of millet collected in different regions of Mali (5.8 and $2.9 \mathrm{mg} / 100 \mathrm{~g}$ corresponding to 6.4 and $3.2 \mathrm{mg} / 100 \mathrm{~g} \mathrm{DM}$, respectively) (Barikmo et al., 2007). Authors pointed out the considerable variability in mineral, and particularly iron, content of cereal, across the region of origin.

Fibre and ash contents decreased during processing due to the removal of hulls during the sieving step. Protein and lipid contents in gruels also decreased but to a lesser extent, and were highly variable. In the grains, proteins and lipids are mainly located in the germ. Depending on the fineness of the wet flour milling, and on the mesh size during sieving, a varying proportion of the germs is removed simultaneously with the hulls, which probably explains the final high variability of protein and lipid contents. Processing also results in a considerable decrease in total iron and zinc. These losses are mainly due to leaching of soluble minerals during the soaking step (Lestienne et al., 2005a). For protein content only, a positive correlation was found between the initial content in the millet grain and the final content in the gruel $(n=14, p<0.05)$. This means that the use of pearl millet genotypes that are rich in protein would enable preparation of gruels with higher protein contents. However, the increase that could be obtained in this way is limited. Concerning the final lipid content, processing (particularly the step of sieving) appears to have a greater effect than the initial lipid content of the grain used. 
As shown in Table 4, mean glucose and fructose contents, which are very low in raw millet grains, increased dramatically in fermented gruels, whereas sucrose content, which was initially rather high, fell dramatically. This decrease in sucrose content during processing was observed in all samples and the average percentage of variation approached $100 \%$. This may be explained by the action of a microbial invertase during fermentation, which hydrolyses the sucrose into glucose and fructose, thus helping increase the contents of these sugars. Then, as glucose and fructose are substrates for the lactic acid bacteria during fermentation, their final contents in the gruels were highly variable.

Maltose was not detected in raw millet grains, but was present at concentrations above $0.01 \mathrm{~g} / 100 \mathrm{~g} \mathrm{DM}$ in 36 gruel samples out of 47 , the maximum value being $0.52 \mathrm{~g} / 100 \mathrm{~g}$ DM. The appearance of maltose, even in small quantities, is likely due to very partial starch hydrolysis under the action of amylolytic strains of lactic acid bacteria (ALAB) in certain production units. The isolation and use of ALAB as starter culture, as proposed by Nguyen et al. (2007) for rice-based gruels, could be a way of increasing the energy density of the gruel by reducing their viscosity at high concentration through partial starch depolymerisation. This phenomenon would also help increase glucose content.

Similar as for sucrose, there was a marked decrease in raffinose and stachyose contents in most samples, with the simultaneous appearance of small quantities of melibiose (table 5). The decrease in raffinose and stachyose may be due to leaching into the water during soaking as well as hydrolysis by bacterial -galactosidase during fermentation. This can be regarded as a positive effect as -galactosides are responsible for digestive disorders in infants, as they are indigestible and fermented by intestinal microflora in the colon causing flatulence. However, it would only be of real interest in the case of cofermentation of millet with legumes, since the initial -galactoside content of millet is moderate. Factors such as phytate and iron-binding phenolic compounds, which have chelating effect and thus reduce mineral bioavailability, also decreased during fermentation (table 5). The extent of this decrease varied considerably from one production unit to another, and the maximum decrease observed was $86.3 \%$ and $68.0 \%$ for phytate and iron-binding phenolic compounds respectively. El Hag et al. (2002) also reported decreases in the contents of phytate and polyphenol in millet-based fermented dough prepared at laboratory scale. In their experiments, phytate and polyphenols were reduced by respectively $50 \%$ and $66 \%$ after $12 \mathrm{~h}$ of fermentation. These decreases can be partially explained by the leaching of the soluble part of polyphenols and phytates during the soaking step, but this is not enough to explain the decrease of more than $29 \%$ in phytate content (Lestienne et al., 2005a and b). Additional losses are likely due to a partial removal of germs, which contains about $60 \%$ of the phytate of the grains (Abdelrahman et al., 1984), during sieving or to degradation through hydrolysis by endogenous or microbial phytase or polyphenoloxydase during fermentation (Lopez et al., 1983; Khetarpaul and Chauhan, 1989). This also suggests that the isolation and use as starter culture of bacterial strains with high phytase or polyphenol oxydase activities could improve the bioavailability of minerals in fermented gruels. Indeed, even if polyphenols can have also positive effects as antioxidants as described by Dykes and Rooney (2006), their negative role as mineral-chelating agent might 
be of greater importance in the context of young child feeding in developing countries, given the low micronutrient availability in their food diet (Zimmermann and Hurrell, 2007).

Final fermented millet gruels had an average total lactic acid content of $197.4 \pm 56.1 \mathrm{mg} / 100 \mathrm{~g}$ of gruel (with a maximum value of $342.4 \mathrm{mg} / 100 \mathrm{~g}$ ), far below that of yogurt, which is around $1 \mathrm{~g} / 100 \mathrm{~g}$. The determination of $\mathrm{D}$-lactic acid content revealed its presence in all gruel samples in non-negligible proportions: gruels contained an average of $62.3 \mathrm{mg}$ of D-lactic acid/100 $\mathrm{g}$ of gruel, representing $32.2 \%$ of the total lactic acid formed during fermentation. To our knowledge, few data on D-lactic acid content in African fermented cereal-based gruel are available in the literature. Nout et al. (1989) reported that D-lactic acid represent about $42 \%$ of total acidity in a modified sorghum-based gruel, and, according to Yusof (1993), the main lactic acid bacteria strains involved in the processing of fermented cereal products produce a mixture of D- and L-lactate. The presence of the D-isomer in non-negligible quantities is not surprising since the natural microflora responsible for cereal fermentation are a mixture of lactic acid bacteria belonging to different metabolic groups. In the human body, D-lactic acid is metabolized more slowly than its chiral isomer L-lactic acid (Urribari et al., 1998). This may be a problem in newborn infants due to renal immaturity which limits the excretion of hydrogen ions by the kidney (Mack, 2004), for whom ingestion of large quantities of D-lactic acid could result in its accumulation in the blood and consequently in metabolic acidosis. However, young children are not concerned by this issue as the international recommendation not to add $D$ or DL-lactate concerns food destined for infants less than three months old (FAO/WHO, 1974; Yusof, 1993). And the D-lactate load that can be ingested through the consumption of fermented gruel is much lower than that absorbed from yoghurt by healthy adults in the study of de Vrese and Barth (1991), which had no harmful effects.

As previously mentioned, sugar is almost always added to fermented millet before consumption. Therefore, the nutritional properties of fermented gruels as eaten were calculated taking into account the addition of sugar and were then compared to recent recommendations for complementary foods (table 6). Due to the very low dry matter content of traditional fermented millet gruels, the added sugar represents a large proportion ( $>40 \%$ ) of the dry matter of the gruel eaten. The addition of sugar led to an increase in the mean gruel energy density from about $109 \mathrm{~kJ} / 100 \mathrm{~g}$ to $180 \mathrm{~kJ} / 100 \mathrm{~g}$ (26 to $43 \mathrm{kcal} / 100 \mathrm{~g}$ ). However, as sugar contains mainly "empty" calories, this increase is limited to energy, and other macronutrient (protein and lipid) or micronutrient (iron and zinc) contents are even further below recommended levels. And anyway, the final energy density of gruel after the addition of sugar is still far below the recommended value of $351 \mathrm{~kJ} / 100 \mathrm{~g}$ (84 kcal/100g).

\section{Conclusion}

The survey of households in Ouagadougou showed that a large proportion of young children receive traditional fermented millet gruels as complementary food. These gruels are well accepted from an organoleptic viewpoint and mothers appreciate them because they are relatively cheap and practical (as they are sold in ready-to-eat form). The most frequently cited problems of quality of ben-kida and ben-saalga gruels are their unreliable hygienic quality and 
poor nutritional quality. Actually, the low $\mathrm{pH}$ and the high lactic acid content (which has antiseptic properties) of ben-kida and ben-saalga, thanks to the lactic acid fermentation that occurs during processing, can be expecting to offer some protecting effect against growth and survival of food-borne pathogens.

Due to processing and mainly to fermentation, the biochemical composition of gruel differs from that of raw millet. The putative diversity of lactic acid microflora and differences in the know-how of producers means these changes vary considerably from producer to producer. These assumptions are supported by the fact that, although -galactoside and phytate contents generally decreased during processing, their final contents in gruels varied considerably from one production unit to another. It would be interesting to explore the possibility of optimizing the degradation of phytate and -galactoside by the use of starter cultures selected for their marked phytasic or -galactosidasic activity.

In all samples, final energy density and macronutrient contents were very low, far below the recommendations for adequate complementary foods. Concerning iron and zinc contents, a positive influence of the decrease in factors that have a chelating effect (phytate, iron-binding phenolic compounds and insoluble fibres) on their bioavailability would be expected in traditional fermented millet gruels, but losses of soluble minerals due to processing result in very low final total mineral contents.

Thus, improvement of the nutritional quality of traditional gruels requires many modifications to simultaneously increase energy, and macro- and micro- nutrient densities. The decrease in mineral-chelating factors achieved by processing would then be useful to improve bioavailability of both intrinsic and extrinsic (added by fortification) minerals.

\section{Acknowledgments}

The authors wish to express their thanks to C. Picq and I. Lestienne for technical assistance with analyses of proximate composition, minerals, and phenolic compounds. This work is part of the Cerefer project (www.mpl.ird.fr/cerefer) funded by European Commission Contract NICA4-CT-2002-10047.

\section{References}

Abdelrahman A, Hoseney RC, Varriano-Marston E. 1984. The proportions and chemical compositions of hand-dissected anatomical parts of pearl millet. J Cereal Sci 2: 127-133.

Abebe Y, Bogale A, Hambidge KM, Stoecker BJ, Bailey K, Gibson RS. 2007. Phytate, zinc, iron and calcium content of selected raw and prepared foods consumed in rural Sidama, Southern Ethiopia, and implications for bioavailability. J Food Comp Anal 20(3-4): 161168.

Barikmo I, Ouattara F, Oshaug A. 2007. Differences in micronutrients content found in cereals from various parts of Mali. 6th International Food Data Conference. J Food Compos Anal 20(8): 681-687.

Blandino A, Al-Aseeri M, Pandiella S, Cantero D, Webb C. 2003. Cereal-based fermented foods and beverages. Food Res Int 36: 527-543. 
Buerkert A, Moser M, Kumar AK, Fürst P, Becker K. 2001. Variation in grain quality of pearl millet from Sahelian West Africa. Field Crops Res 69: 1-11.

Brune M, Rossander L, Hallberg L. 1989. Iron absorption and phenolic compounds: importance of different phenolic structures. Eur J Clin Nutr 43: 547-558.

Calderon M, Loiseau G, Guyot JP. 2001. Nutritional requirements and simplified cultivation medium to study growth and energetics of a sourdough lactic acid bacterium Lactobacillus fermentum Ogi E1 during heterolactic fermentation of starch. J Appl Microbiol 90: 508-516.

Chavan JK, Kadam SS. 1989. Nutritional improvement of cereals by fermentation. Critical Rev Food Sci Nutr 28: 349-400.

De Vrese M, Barth CA. 1991. Postprandial plasma D-lactate concentrations after yogurt ingestion. Zeitschrift für Ernärhungswissenschaft 30, 131-137.

Dewey KG, Brown KH. 2003. Update on technical issues concerning complementary feeding of young children in developing countries and implications for intervention programs. Food Nutr Bull 24, 5-22.

Dykes L, Rooney LW. 2006. Sorghum and millet phenols and antioxidants. J Cereal Sci_44(3): 236-251.

El Hag M, El Tinay A, Yousif N. 2002. Effect of fermentation and dehulling on starch, total polyphenols, phytic acid content and in vitro protein digestibility of pearl millet. Food Chem 77, 193-196.

FAO. 1995. Sorghum and millet in human nutrition. FAO Food and Nutrition Series, $\mathrm{N}^{\circ} .27$, Rome (Italy). $198 \mathrm{p.}$

FAO/WHO. 1974. Toxicological evaluation of certain food additives with a review of general principles and of specifications. WHO Tech Rep Ser 539, 1-40.

Khetarpaul N, Chauhan BM. 1989. Effect of fermentation by pure cultures of yeasts and lactobacilli on phytic acid and polyphenol content of pearl millet. J Food Sci 54, 780-781.

Kingamkono R, Sjogren E, Svanberg U, Kaijser B. 1994. pH and acidity in lactic-fermenting cereal gruels: effect on viability of enteropathogenic microorganisms. World J Microbiol Biotechnol 10, 664-669.

Laporte J, Kovacsik G, Pinta M. 1980. Milieux végétaux. In: Pinta M, Spectrométrie d'absorption atomique, Tome 2: Applications à l'analyse chimique, 2nd ed. Masson, Paris. 378-421.

Lei V, Jakobsen M. 2004. Microbiological characterization and probiotic potential of koko and koko sour water, African spontaneously fermented millet porridge and drink. J Applied Microbiol 96, 384-397.

Lestienne I, Icard-Vernière C, Mouquet C, Picq C, Trèche S. 2005a. Effects of soaking whole cereal and legume seeds on iron, zinc and phytate contents. Food Chem 89, 421-425.

Lestienne I, Mouquet-Rivier C, Icard-Vernière C, Rochette I, Trèche S. 2005b. The effects of soaking of whole, dehulled and ground millet and soybean seeds on phytate degradation and Phy/Fe and Phy/Zn molar ratios. Int J Food Sci Technol 40, 391-399.

Lopez Y, Gordon DT, Fields ML. 1983. Release of phosphorus from phytate by natural lactic acid fermentation. J Food Sci 48, 953-954. 
Lutter CK, Dewey KG. 2003. Nutrient composition for fortified complementary foods: proposed nutrient composition for fortified complementary foods. J Nutr 133, 3011S3020 S.

Mack D. 2004. D(-)-lactic acid-producing probiotics, D(-)-lactic acidosis and infants. Can J Gastroenterol 18, 671-675.

McKevith B. 2004. Nutritional aspects of cereals. Nutr Bull 29, 111-142.

Mensah P, Tomkins A. 2003. Household-level technologies to improve the availability and preparation of adequate and safe complementary foods. Food Nutr Bull 24, 104-125.

Mouquet C, Greffeuille V, Trèche S. 2006. Characterization of the consistency of gruels consumed by infants in developing countries: assessment of the Bostwick consistometer and comparison with viscosity measurements and sensory perception. Int J Food Sci Nutr 57, 459-69.

Nguyen TTT, Loiseau G, Icard-Verniere C, Rochette I, Treche S, Guyot JP. 2007. Effect of fermentation by amylolytic lactic acid bacteria, in process combinations, on characteristics of rice/soybean slurries: A new method for preparing high energy density complementary foods for young children. Food Chem 100(2): 623-631.

Nout MJR, Rombouts FM, Hautvast GJ. 1989. Accelerated natural lactic fermentation of infant food formulations. Food Nutr Bull 11(1), 65-73.

Ouattara CAT, Savadogo A, Bayane Y, Traore SA. 2006. A comparative study on nutritional and technological quality of fourteen (14) cultivars of pearl millets [Pennisetum glaucum (L) Leeke] in Burkina Faso. Pakistan J Nutr 5, 512-521.

Simango C. 1995. Effective acidification of traditional fermented foods. J Trop Med Hyg 98: 465-468.

Talamond P, Gallon G, Trèche S. 1998. Rapid and sensitive liquid chromatographic method using a conductivity detector for the determination of phytic acid in food. J Chromatography A 805, 143-147.

Tou EH, Guyot JP, Mouquet-Rivier C, Rochette I, Counil E, Traore AS, Trèche S. 2006. Study through surveys and fermentation kinetics of the traditional processing of pearl millet (Pennisetum glaucum) into ben-saalga, a fermented gruel from Burkina Faso. Int J Food Microbiol 106, 52-60.

Trèche S, Mbome L. 1999. Viscosity, energy density and osmolality of gruels for infants prepared from locally produced commercial flours in some developing countries. Int J Food Sci Nutr 50, 117-125.

Uribarri J, Oh M, Carroll H. 1998. D-lactic acidosis. A review of clinical presentation, biochemical features, and pathophysiologic mechanisms. Medicine (Baltimore) 77, 73-82.

Van Soest PS. 1963. Use of detergents in the analysis of fibrous feeds II- A rapid method for the determination of fiber and lignin. J AOAC 46, 829-835.

Yusof Y, Mazian M, Ibrahim N, Jusoh NM. 1995. Infant feeding practices and attitudes of mothers in Kelantan towards breastfeeding. Med J Malaysia 50, 150-155.

Zimmermann MB, Hurrell RF. 2007. Nutritional iron deficiency. The Lancet 370, 511-520. 
International Journal of Food Sciences and Nutrition, 2008, 59(7), 716 - 729 
Table 1. Frequency and mode of consumption of ben-kida and ben-saalga as a function of age in $\mathrm{CH}$.

\begin{tabular}{lccccccc}
\cline { 2 - 5 } & $\begin{array}{c}\text { Adults } \\
>17 \text { yrs }\end{array}$ & $12-17$ yrs & $6-11$ yrs & $2-5$ yrs & $<2$ yrs & Total \\
\hline $\begin{array}{l}\text { Number of people in the } \\
\text { 159 CH }\end{array}$ & 254 & 119 & 136 & 105 & 30 & 644 \\
\hline
\end{tabular}

People who consumed the last fermented gruel that was purchased by the household (\%)

\begin{tabular}{|c|c|c|c|c|c|c|}
\hline & 63 & 59 & 63 & 71 & 80 & 64 \\
\hline \multicolumn{7}{|c|}{ Frequency of consumption (\%) } \\
\hline Daily & 44 & 42 & 49 & 59 & 69 & 48 \\
\hline From 1 to 6 times/week & 44 & 52 & 45 & 38 & 27 & 44 \\
\hline Less than once a week & 12 & 6 & 6 & 3 & 4 & 8 \\
\hline \multicolumn{7}{|c|}{ Meal times that gruel was eaten (\%) } \\
\hline Before 8 am & 89 & 91 & 93 & 94 & 97 & 91 \\
\hline Between 8 am and 12 pm & 3 & 6 & 3 & 2 & 0 & 3 \\
\hline Between 2 pm and 6 pm & 6 & 2 & 3 & 3 & 3 & 4 \\
\hline After 6 pm & 2 & 1 & 0 & 1 & 0 & 1 \\
\hline \multicolumn{7}{|c|}{ Ingredients added to gruel before consumption (\%) } \\
\hline Sugar & 96 & 96 & 99 & 100 & 100 & 98 \\
\hline Millet cake & 22 & 28 & 16 & 11 & 10 & 20 \\
\hline Bread & 3 & 6 & 4 & 5 & 0 & 4 \\
\hline
\end{tabular}


Table 2. Physicochemical characteristics of pearl millet and fermented gruels

\begin{tabular}{|c|c|c|c|c|}
\hline & Number & $\begin{array}{l}\text { Mean } \\
\text { value }\end{array}$ & $\begin{array}{l}\text { Standard } \\
\text { deviation }\end{array}$ & Range \\
\hline DM content of pearl millet (\%) & 47 & 91.99 & 1.49 & $88.40-95.20$ \\
\hline \multicolumn{5}{|l|}{ DM content of gruel (\%) } \\
\hline Ben-saalga & 9 & 7.06 & 1.02 & $5.53-8.09$ \\
\hline Ben-kida & 39 & $6.50(6.44)^{1}$ & 1.02 & $5.02-10.24$ \\
\hline Together & 48 & $6.61(6.45)^{1}$ & 1.03 & $5.02-10.24$ \\
\hline \multicolumn{5}{|l|}{ Bostwick flow (mm/30s) } \\
\hline Ben-saalga & 2 & -- & -- & $110->240^{2}$ \\
\hline Ben-kida & 24 & 129 & 26 & 70-172 \\
\hline Together & 26 & $128^{2}$ & 26 & $70->240$ \\
\hline \multicolumn{5}{|l|}{$\mathrm{pH}$} \\
\hline Ben-saalga & 9 & 3.88 & 0.08 & $3.75-4.00$ \\
\hline Ben-kida & 38 & 4.00 & 0.14 & $3.75-4.47$ \\
\hline Together & 47 & $3.98(3.96)^{1}$ & 0.14 & $3.75-4.47$ \\
\hline
\end{tabular}

\footnotetext{
${ }^{1}$ Median value is given in brackets

${ }^{2}$ Only 2 values were collected

${ }^{3}$ This value was calculated without the only gruel whose consistency was too fluid to be measured with the Bostwick apparatus (value $>240 \mathrm{~mm} / 30 \mathrm{~s}$ ), and was thus considered to be an outlier.
} 
Table 3. Proximate composition and iron and zinc contents of pearl millet and fermented gruels

\begin{tabular}{|c|c|c|c|c|c|c|c|c|}
\hline & \multirow{2}{*}{$\begin{array}{c}\text { Average } \\
\text { sample of } \\
\text { pearl millet }^{1} \\
\text { Mean }^{2}\end{array}$} & \multicolumn{3}{|c|}{$\begin{array}{l}\text { Pearl millet grains } \\
n=14\end{array}$} & \multicolumn{3}{|c|}{$\begin{array}{c}\text { Fermented gruel } \\
\text { (ben-kida or ben-saalga) } \\
\mathrm{n}=47\end{array}$} & \multirow[t]{2}{*}{$\begin{array}{c}\text { Change } \\
(\%)^{3}\end{array}$} \\
\hline & & Mean & $\begin{array}{l}\text { Standard } \\
\text { deviation }\end{array}$ & Range & Mean & $\begin{array}{l}\text { Standard } \\
\text { deviation }\end{array}$ & Range & \\
\hline Proteins (g/100g DM) & 9.68 & 9.28 & 0.93 & $8.33-11.7$ & 8.22 & 0.87 & $5.77-9.96$ & -15 \\
\hline Lipids (g/100g DM) & 5.31 & 5.24 & 0.34 & $4.69-5.71$ & 4.69 & 0.76 & $2.54-6.63$ & -12 \\
\hline Fibres (g/100g DM) & 2.87 & 2.64 & 0.51 & $1.91-3.60$ & 2.14 & 0.48 & $1.27-3.18$ & -25 \\
\hline Ash (g/100g DM) & 2.03 & 2.03 & 1.18 & $1.35-5.98$ & 1.41 & 0.20 & $0.90-1.82$ & -31 \\
\hline Iron (mg/100g DM) & 22.7 & 21.2 & 22.0 & $4.79-73.5$ & 8.33 & 2.83 & $3.82-15.0$ & -63 \\
\hline Zinc (mg/100g DM) & 2.47 & 2.66 & 0.74 & $1.85-4.04$ & 2.05 & 0.51 & $1.07-3.20$ & -17 \\
\hline
\end{tabular}

${ }_{1}^{1}$ average sample prepared by blending the 47 samples of raw pearl millet - ${ }^{2}$ mean of 2 measurements $-{ }^{3}$ percentage of change between the mean final content of gruels and the initial content of raw pearl millet measured on the average sample of raw pearl millet on the basis of initial content 
International Journal of Food Sciences and Nutrition, 2008, 59(7), 716 - 729

Table 4. Soluble sugar contents of pearl millet and fermented gruels

\begin{tabular}{|c|c|c|c|c|c|c|c|c|c|c|}
\hline & \multirow{2}{*}{$\begin{array}{c}\begin{array}{c}\text { Average } \\
\text { sample of } \\
\text { millet }^{1}\end{array} \\
\text { Mean }^{2}\end{array}$} & \multicolumn{4}{|c|}{ Pearl millet } & \multicolumn{4}{|c|}{$\begin{array}{c}\text { Fermented gruel } \\
\text { ben-kida \& ben-saalga }\end{array}$} & \multirow[t]{2}{*}{$\begin{array}{l}\text { Change } \\
(\%)^{3}\end{array}$} \\
\hline & & $n$ & $\begin{array}{l}\text { Mean } \\
\text { value }\end{array}$ & $\begin{array}{l}\text { Std } \\
\text { dev. }\end{array}$ & Range & $n$ & $\begin{array}{l}\text { Mean } \\
\text { value }\end{array}$ & $\begin{array}{r}\text { Std } \\
\text { dev. }\end{array}$ & Range & \\
\hline Glucose (g/100 g DM) & 0.063 & 13 & 0.07 & 0.007 & $0.05-0.08$ & 47 & 0.61 & 0.543 & $0.01-2.64$ & 868 \\
\hline Fructose (g/100 g DM) & 0.038 & 14 & 0.04 & 0.005 & $0.03-0.05$ & 47 & 0.18 & 0.139 & $0.001-0.49$ & 374 \\
\hline Sucrose (g/100 g DM) & 1.513 & 14 & 1.51 & 0.010 & $1.24-1.66$ & 47 & 0.04 & 0.07 & $0.000-0.32$ & -97 \\
\hline Maltose (g/100 g DM) & n.d. & 14 & n.d. & - & - & 47 & 0.11 & 0.137 & $0.000-0.52$ & - \\
\hline
\end{tabular}

${ }_{1}$ average sample prepared by blending identical aliquots of dry matter of the 47 samples of raw pearl millet

${ }^{2}$ mean of 2 measurements

${ }^{3}$ percentage of change between the mean value obtained from $n$ samples of raw pearl millet and the mean value obtained from corresponding gruels on the basis of initial content.

${ }^{4}$ n.d. $=$ not detected 
Table 5. Factors reducing nutrient bioavailability and D-lactic acid contents of pearl millet and fermented gruels

\begin{tabular}{llll}
\hline $\begin{array}{l}\text { Average } \\
\text { sample of } \\
\text { millet }^{1}\end{array}$ & Pearl millet & $\begin{array}{l}\text { Fermented gruel } \\
\text { ben-kida \& ben-saalga }\end{array}$ & Change $^{3}$ \\
\hline
\end{tabular}

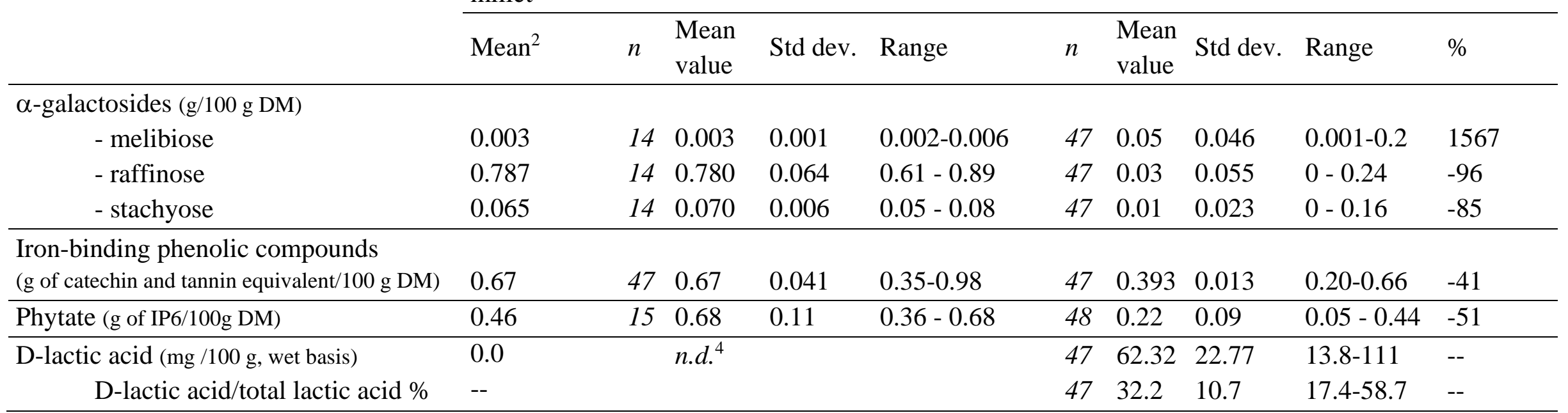

\footnotetext{
${ }^{1}$ average sample prepared by blending identical aliquots of dry matter of the 47 samples of raw pearl millet.

${ }^{2}$ mean of 2 measurements

${ }^{3}$ percentage of change between the mean final content of gruels and the initial content of raw millet measured in the average sample of raw pearl millet on the basis of initial content.

${ }^{4}$ n.d. $=$ not detected
} 

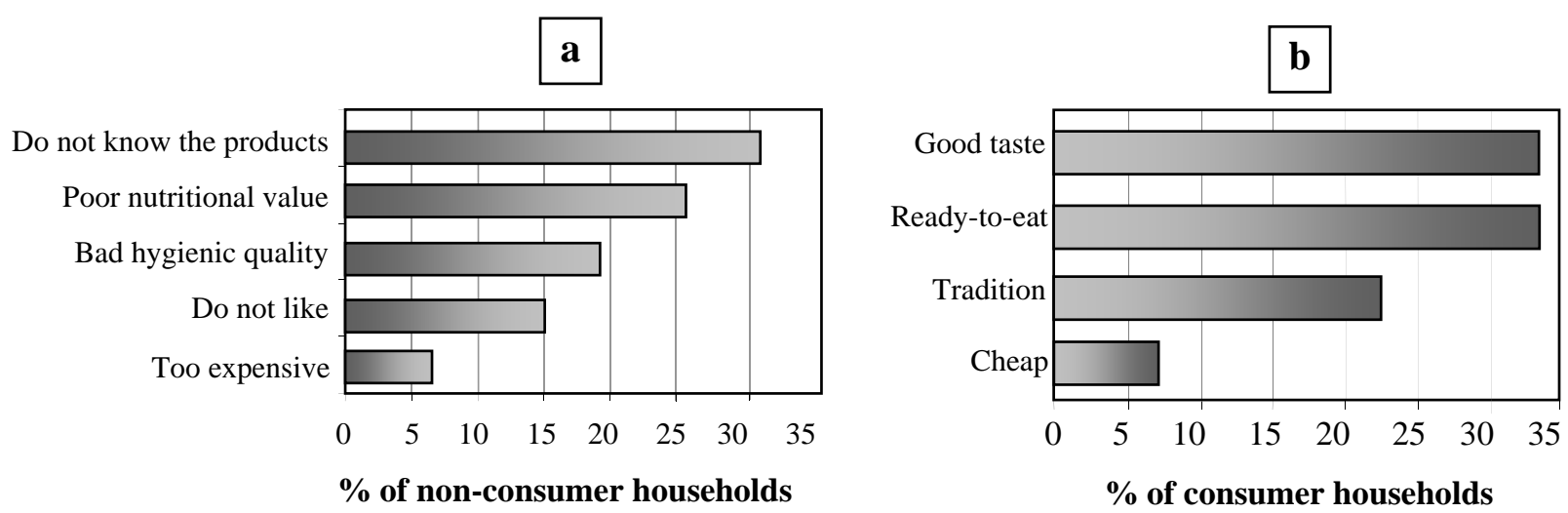

Figure 1. Main reasons cited by households for not consuming (a) or for consuming ben-kida or ben-saalga (b)

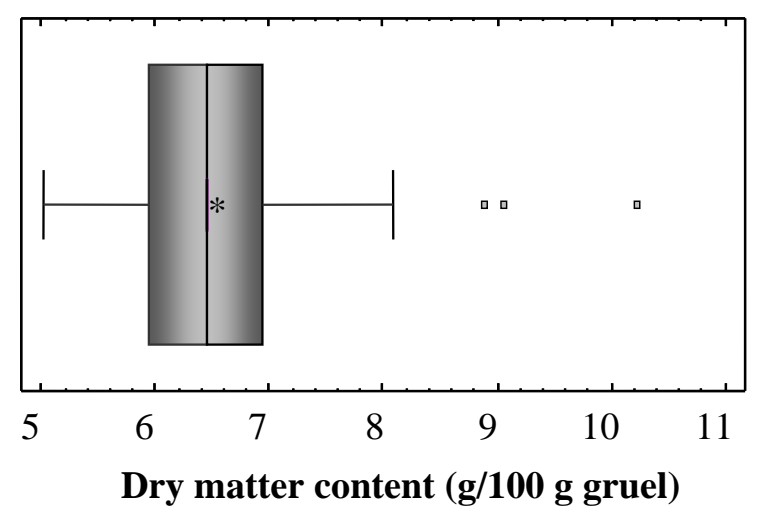

Figure 2. Box and Whisker plot of the dry matter content of the fermented pearl millet gruels collected in Ouagadougou 


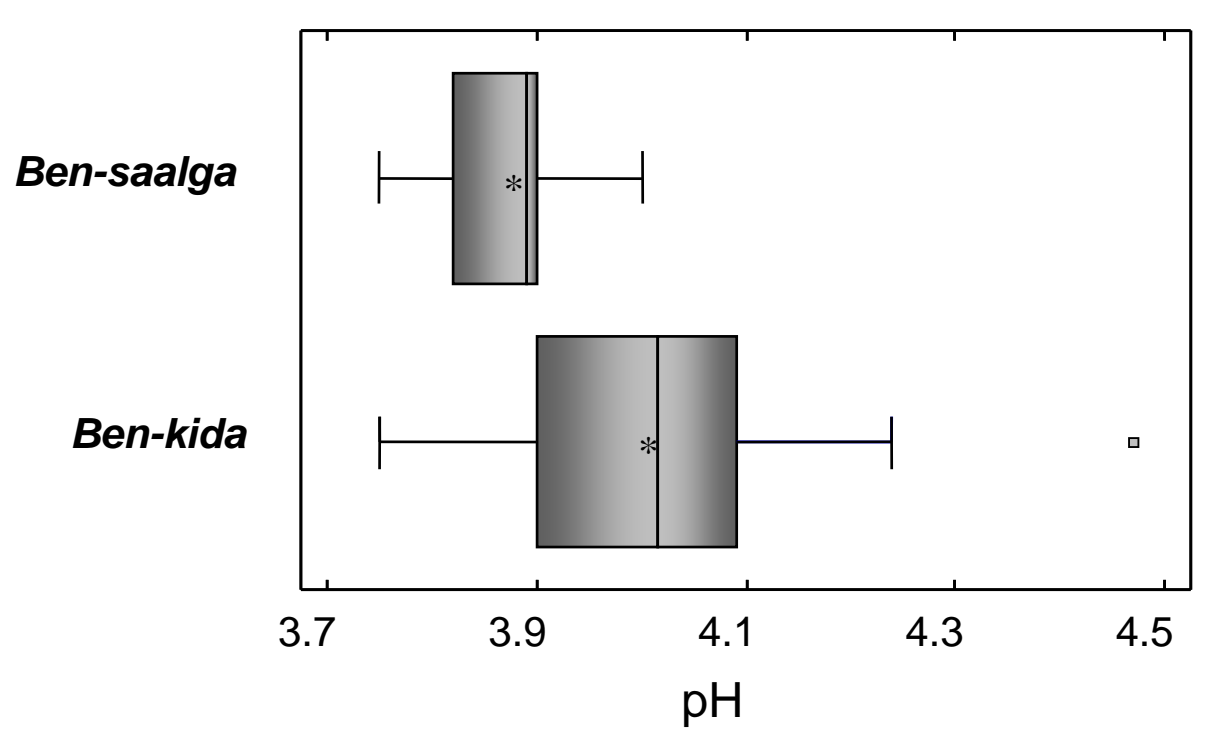

Figure 3. Box and Whisker plots of the $\mathrm{pH}$ of the fermented pearl millet gruels ben-kida and ben-saalga collected in Ouagadougou 